\title{
Study on the Financial Support Mechanism of Enterprise in Development Zone
}

\author{
QinYun Wang \\ School of Economics, Shanghai University, 99 Shangda Road, Shanghai, China \\ shuolivia@163.com
}

Keywords: Baoshan industrial zone; TFP; Impact mechanism; Policy recommendations

\begin{abstract}
By using the data of Baoshan Industrial Park Committee, this paper empirically tests the difference between total factor productivity and non-Development Zone enterprises in the development zone. At the same time, combined with the theoretical analysis and empirical methods, tests the impact mechanism of TFP (Factor Productivity Total) of the development zone policy. Past industrial policy and regional policy are often randomly, while this paper provides a scientific basis for specific policy development to different industries and regions through rigorous academic research and empirical analysis, hereby reducing copycats and reduce market distortions. This paper provides the Government with both scientific and operational policy recommendations.
\end{abstract}

\section{Introduction}

The development zone is to set aside a certain range in a country or region, and then develop this region by more advanced operation mode, and with special policies and methods by the absorption of external resource. The establishment of the development zone effectively promotes the industry modernization and accelerates the speed of city modernization.

By March, 2016, China has 4 special economic zones, respectively, the Shantou Special Economic Zone, the Zhuhai Special Economic Zone, the Shenzhen special economic zone and the Xiamen special economic zone.378 various types of national key development zones have been established, including 219 state-level economic development zones, 146 state-level high-tech development zones and 13 national bonded warehouse areas. In addition, there are a number of provincial development zones in unit of province.

National Development Zone, except for the special economic zone, also includes six other categories. The first national economic and technological Development Zone was approved in 1984, and by March, 2016, there were 219 state-level economic development zones in China; The first High tech Development Zone was approved in 1991, to March, 2016, there were total 146 high-tech development zone around the country. The intention of setting up free trade zone is to promote the export processing and export trade and expand exports, from the beginning of 1990, 15 ones were established in 1996, and there have been 13 national free trade zones by March, 2016;Export processing zones were set up late in 1992, Shanghai Caohejing export processing zone was the first approved one, and next export processing zone will usher in a period of vigorous development, by March, 2016, there have been a total of more than 63 national export processing zones across the country; In addition, the national border economic cooperation zone in 1992 alone approved the establishment of 14, in order to promote inland open border area more effectively.

In general, three kinds of development zones: export processing zone, high tech Industrial Park and economic and Technological Development Zone, are the most important national development zones. Due to their different functions, three types of development zone, in terms of investments, have different preference. Compared with other parts of the world, China's export processing zones are similar with other processing areas in function, the main purpose is to avoid the complexity of the rules of trade restrictions on imports and exports. Related high-tech industries and enterprises can enjoy the preferential policies of the government, and thus to achieve leapfrog development. 
The economic and technological Development Zone and economic zone are relatively similar in function, with strong comprehensive characteristics, except to avoid trade control, but also shoulder the dual task of the system innovation and experiment and promotion of the development of regional economy.

This paper is mainly divided into three parts, first of all, it estimates whether the industrial park enterprises have a higher productivity. Secondly, examines the impact of financial support mechanism on the performance of enterprises, and finally puts forward the policy recommendations. In other words, this part answers the following questions through the empirical method: What is the influence of the development zone policy on enterprise production behavior? How big are these effects? And what channels and channels these impacts are mainly through? With the rigorous data, validate the relationship between zone policy and business efficiency as well as the mechanisms.

\section{The Influence of Development Zone Policy on Enterprise Efficiency}

Data Illustration. The enterprise level data used in this paper is from the database of Chinese industrial enterprises in 1998-2007.On the one hand, the database contains all the state-owned enterprise data, on the other hand, includes 30 non state owned enterprises of two digits industry and the annual sales amount of which is greater than or equal to five million. The database includes the following data: enterprise age, number of employees, the export delivery value, new industry code, total assets, total asset, correction of enterprise address, industrial added value, total intermediate inputs, long-term investment and the enterprise balance sheet including main financial index. TFP estimation and model assumptions of impact on corporate efficiency of development zone. In order to analyze the influence of the Development Zone on the production efficiency of the enterprises in the park, this part is mainly divided into two steps. Firstly, identify of the Development Zone enterprises. If the enterprise is located in a district (county) administrative area, it must include the following key words: township (town), village (street, building), street office, and street committee. Therefore, we determine whether the enterprise is located in the Development Zone according to the following method: if an enterprise name contains keywords of "development", "Industrial Park", "Industrial Park" and "Park" and "high tech", the enterprise is located in the development zone. Secondly, measure total factor productivity (TFP). We use the previously mentioned OP method and the GMM method to calculate the total factor productivity of enterprises. OP method and GMM method have their own advantages. The main advantages of OP method are: comprehensively considerate the impact of corporate efficiency on corporate investment decisions; and comprehensively considerate the factors affecting the survival probability of enterprises. Therefore, the OP method can solve the problem of two-way causality and sample self-selection simultaneously, which cannot be achieved simultaneously by the method of parameter and non-parametric method. GMM method has the statistical idea and the statistical nature is richer, profound. And the GMM method does not need to consider the problem of model setting and setting error, because it is to estimate the parameters from moment method.

\section{The Impact Mechanism of Development Zone Policy on the Efficiency of Enterprises}

Financial Support for the Development Zone TFP Mechanism of Action. Development Zone enterprises not only enjoy tax concessions, but also enjoy a variety of forms of financial incentives. Especially in terms of financing channels and interest rates, the development zone enterprises are more likely to obtain loans than other enterprises, and can enjoy the bank's interest subsidies; In some areas, the development zone enterprises can enjoy a great interest, such as government regulates that interests can be used to offset income tax. Development Zone enjoy the preferential treatment in this area, on the one hand, can have a greater profit retention, on the other hand, will stimulate investment and innovation enterprises, which are likely to improve the level of enterprise TFP. Therefore, we believe that the development zone policy is likely to affect the financial aspects 
of the TFP level of enterprises.

The purpose of this part is to clarify the causal relationship between the policy and financial support of the Development Zone, that is, whether a business enterprise will enjoy the financial benefits by entering the development zone. Of course, before answering this question, we need to make good use of existing literature to analyze the influence mechanism of financial support on industrial development and the theory of the theory.

Model Assumptions and Regression Results. According to the above analysis, we expect to control the other variables in the Development Zone, corporate interest payments will be less than outside the Development Zone enterprises. In addition, the impact of government or financial institutions to provide financial support for enterprises which are the factors that we are very concerned about. Such as the age of the enterprise should affect the enterprise's financial incentives, one hand due to the increasing age of accumulated credit is higher; on the other hand, enterprise age, ability and knowledge of more enterprises through the learning effect of accumulated, the probability of survival is higher, which will give the enterprise to win more preferential loans, which makes the enterprise interest expense is small. In 5.3.1, we analyze the development of preferential tax policies for foreign enterprises have a significant impact, but we expect the financial support, the development of the policy of different sources of capital enterprises have the same impact. At the same time, the financial support of the government or the financial institution to the labor-intensive enterprise and the capital intensive enterprise should be different. On the one hand, labor-intensive enterprises due to poor performance and loans to employees a higher likelihood of wages; on the other hand, because of state support for enterprise innovation and development, making the capital intensive enterprises easier loans, and labor intensive enterprise innovation ability and capital intensive enterprises also have the gap, it is hard to the loan, these two aspects will make the labor-intensive enterprises increase in interest expense. The specific regression results are shown in Table 1.

Table 1 Development Zone and financial support: Panel data FE results

\begin{tabular}{|c|c|c|c|c|}
\hline Variables & $\begin{array}{l}(1) \\
\text { interest } \\
\text { expense }\end{array}$ & $\begin{array}{l}(2) \\
\text { interest } \\
\text { expense }\end{array}$ & $\begin{array}{l}(3) \\
\text { interest } \\
\text { expense }\end{array}$ & $\begin{array}{l}(4) \\
\text { interest } \\
\text { expense }\end{array}$ \\
\hline Age of enterprise & $\begin{array}{l}-5.163 * * \\
(2.133)\end{array}$ & $\begin{array}{l}-4.995 * * \\
(2.173)\end{array}$ & $\begin{array}{l}-5.539^{* * * *} \\
(2.147)\end{array}$ & $\begin{array}{l}-5.372 * * \\
(2.195)\end{array}$ \\
\hline State owned share & $\begin{array}{l}-15.79 * * * \\
(2.454)\end{array}$ & $\begin{array}{l}-16.37 * * * \\
(2.502)\end{array}$ & $\begin{array}{l}-15.63^{* * * *} \\
(2.405)\end{array}$ & $\begin{array}{l}-16.22 * * * \\
(2.471)\end{array}$ \\
\hline Number of employees & $\begin{array}{l}1.805^{* * * *} \\
(0.593)\end{array}$ & $\begin{array}{l}1.822 * * * \\
(0.594)\end{array}$ & $\begin{array}{l}1.790 * * * \\
(0.594)\end{array}$ & $\begin{array}{l}1.808 * * * \\
(0.595)\end{array}$ \\
\hline $\begin{array}{l}\text { Dummy variable ( } 1 \text { located in } \\
\text { development zone, or } 0)\end{array}$ & $-84.33 *$ & $-79.22 *$ & $-87.10 *$ & $-81.95^{*}$ \\
\hline Constant item & $\begin{array}{l}(46.57) \\
-288.0 \\
(1,811)\end{array}$ & $\begin{array}{l}(45.86) \\
-105.9 \\
(1,843)\end{array}$ & $\begin{array}{l}(47.84) \\
-240.8 \\
(1,823)\end{array}$ & $\begin{array}{l}(47.24) \\
-56.54 \\
(1,854)\end{array}$ \\
\hline $\begin{array}{l}\mathrm{N} \\
\mathrm{R}^{2}\end{array}$ & $\begin{array}{l}1,677,733 \\
0.318\end{array}$ & $\begin{array}{l}1,677,733 \\
0.318\end{array}$ & $\begin{array}{l}1,677,733 \\
0.317\end{array}$ & $\begin{array}{l}1,677,733 \\
0.317\end{array}$ \\
\hline
\end{tabular}


Robust standard errors in parentheses

$* * * \mathrm{p}<0.01, * * \mathrm{p}<0.05, * \mathrm{p}<0.1$

Table 1 is the regression result of regression equation (2). From the regression results we can see that the coefficient of Dummy is significantly negative, which is about -84.33 , compared with in the enterprises in the Development Zone, development zone enterprises do get financial support, after controlling for other variables, an enterprise is located in the development zone to reduce interest payments of about 843 thousand and 300 per year this element, in line with our expectations. At the same time, the results are highly robust

\section{Conclusions and Countermeasures}

The empirical results show that, financial support is helpful for improvement of enterprises TFP in the national level, and the monetary policy supports provide a strong protection for the healthy development of the Industrial Park. The Chinese government's financial support policies to the industrial park are mainly reflected in the reduction of financing difficulty and lower loan interest rates. In view of the robust results, instrument manufacturer, and other industries in the industrial park accept strong financial supports, while in other industries are not very significant. Stability tests are not significant in divided areas, and this is because the region selected existing a few instrumentation manufacturers. Therefore, sound policy systems can effectively promote the development of Baoshan industrial park.

In order to solve the problem of difficult financing guarantee, the introduction of loan guarantee institutions can be increased; to establish and perfect the guarantee system, encourage the participation of different economic sectors of capital security small business financing, forming a multi-level, diversified guarantee system, it can not only enhance the financing ability of small and micro enterprises, while also provide bridge financing for small and micro businesses and link. Two enterprises mortgaging, can make full use of park facilities. For example, the industrial park, the Government encouraged local financial institutions to small and micro enterprises in the industrial park to focus on credit support encourages financial institutions to reduce the threshold for financing needs of small and micro businesses within the Park; encourage financial institutions to adopt appropriate credit products, such as industrial park of small and micro businesses.

\section{References}

[1] Aghion, P., Angeletos, G. M., Banerjee, A., \& Manova, K. (2005). Volatility and growth: Credit constraints and productivity-enhancing investment (No. w11349). National Bureau of Economic Research.

[2] Aigner, D. J., \& Chu, S. F. (1968). On estimating the industry production function. The American Economic Review, 58(4), 826-839.

[3] Aigner, D., Lovell, C. K., \& Schmidt, P. (1977). Formulation and estimation of stochastic frontier production function models. journal of Econometrics, 6(1), 21-37.

[4] Arrow, K. (1962). Economic welfare and the allocation of resources for invention. In The rate and direction of inventive activity: Economic and social factors (pp. 609-626). Princeton University Press.

[5] BAKOUROS Y L, MARDAS D C, and VARSAKELIS N C. Science Park, a high tech fantasy: an analysis of the science parks of Greece [J]. Technovation, 2002, 22(2):123-128.

[6] Huang Lewen. Study on the cluster development and the constraints of development zone [J]. Science and management of science and technology, 2010 (4). 
[7] Ji Xin. Research on the thinking and method of evaluation of land output efficiency in Development Zone [D]. Fudan University doctoral thesis, 2012.

[8] Jia Shujun. Research on the path of intensive development of industrial parks in China [J]. Jiangxi province social sciences, 2012 (12): 47-50.

[9] Jiang Xin, and Mr. (2008). The structure of industrial clusters in China, behavior and performance of quantitative research--based on principal component analysis of SCP paradigm of industrial clusters. Industrial technology economics, 27 (10), 108-111.

[10]Huadong Jiang. Study on the integration of the city and the construction of the city --take Sichuan tianfu as an example.

[11]Dinghua Kang. Present situation and Development Countermeasures of eco industrial park -a case study of Guangxi [J]. Productivity, 2009 (13). 